\title{
PEDAGOGICAL STRATEGIES AS AN ACTIVE COMPONENT OF WORKING WITH GIFTED STUDENTS
}

\author{
Djalolova D.F.
}

Associate Professor of "ESMT" Candidate Of Pedagogical Sciences, Bukhara Engineering Technological Institute, Uzbekistan Azimova M.N.

Department Assistant Of “ESMT”, Bukhara Engineering Technological Institute, Uzbekistan Azimova F.K.

Department Assistant Of “ESMT”, Bukhara Engineering Technological Institute, Uzbekistan

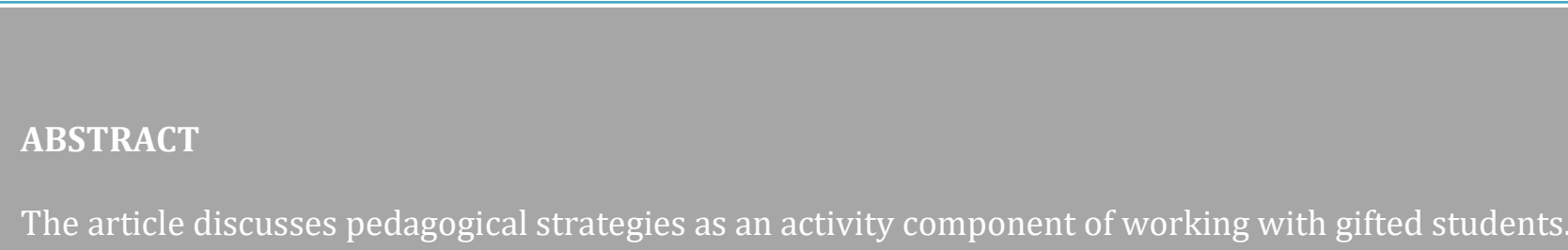

The article discusses pedagogical strategies as an activity component of working with gifted students.

KEYWORDS:- Technology, strategy, method, intellectual, informational, communicative, constructive, design, gnostic, instuition.

\section{INTRODUCTION}

Development of legal foundations for supporting gifted students in the Republic, establishment of an innovative system of teaching and upbringing of gifted students, development of family partnerships, educational institutions and youth associations in working with gifted students, development of a diagnostic apparatus in the selection of gifted students based on advanced foreign experiences, development of technology and social -pedagogical methods is essential. In order to develop a system of work with gifted students and in-depth training of such popular subjects as foreign languages, computer science and mathematics, physics, chemistry and biology, "Action Strategies" draws special attention to the fundamental development of the quality of general secondary education [1].

In general, a pedagogical strategy is understood as a skillful leadership, a consciously constructed set of pedagogical actions adequate to the pedagogical goal, carried out sequentially in stages and developed through a qualitative selection of pedagogical support: the content of the academic discipline (upbringing), the flexible use of forms, methods, techniques and means aimed at implementation of a specific strategy. The pedagogical strategy is viewed, on the one hand, as an activity in which the goal is highlighted, as a strategic reference point, and the means of achieving it. On the other hand, a pedagogical strategy is a process that takes place over time, representing a set of expedient actions 
CURRENT RESEARCH JOURNAL OF PEDAGOGICS 2(11): 47-53, November

2021 DOI: https://doi.org/10.37547/pedagogics-crjp-02-11-11

ISSN 2767-3278

(C)2021 Master Journals

Crossref doi) 81 Google

Accepted 25th November, 2021 \& Published 30 ${ }^{\text {th }}$ November, 2021

aimed at achieving a certain result.

The purpose of working with children with advanced development is a psycho-pedagogically grounded development of a system for working with gifted middle school students based on an integrative approach. This system is aimed at organizing the activities of the teaching staff, ensuring the identification and development of the intellectual and creative abilities of students, the development of the giftedness of students [2]. The following were identified as the main (strategic) goals:

- identification of gifted children - the intellectual resource of the country;

- development of the abilities of gifted children;

- focus on personal self-development;

- reaching the maximum level of development of the child's abilities;

- creating conditions for the manifestation of abilities.

We ranked among the more private (tactical) goals:

- helping the student develop the ability to independently plan, organize, make decisions and evaluate their work;

- providing the student with the opportunity to realize himself in the chosen field;

- give the child a sense of involvement in the task, self-confidence, satisfaction with creativity.

- Based on a set of tasks for the development of giftedness, identified in the research and classified as:

- educational,

- educational and developmental;

- developing;
- development of already high abilities;

- development of insufficiently developed abilities (including communicative and personal);

- pedagogical support;

- development of special educational and developmental technologies, etc .;

- we have identified tasks: educational and developmental; pedagogical support; development of special technologies for working with gifted students.

In accordance with the initial positions of A.M. Matyushkin, E.S. Belova and others, three main approaches to teaching and developing gifted students were taken into account [3]:

a) didactic, when creative learning is built in the direction of expanding and deepening the educational material in accordance with the logic of academic subjects corresponding to a given type of giftedness;

b) didactic-psychological, combining a high level of subject teaching with psychological methods of developing the abilities and personality of the student;

c) psychological and didactic (or psychodidactic), which is characterized by the priority use of the psychological foundations of developmental education as the initial basis for building the educational process and the educational environment as a whole.

Of the three theories listed above, we chose the psychological-didactic approach as the most appropriate to the priority tasks of our experiment. Educational and developmental tasks and a didactic-psychological approach dictated the need to determine the level and characteristics of the educational activity of gifted students. 
CURRENT RESEARCH JOURNAL OF PEDAGOGICS 2(11): 47-53, November

2021 DOI: https://doi.org/10.37547/pedagogics-crjp-02-11-11

ISSN 2767-3278

(C)2021 Master Journals

Crossref doi) 81 Google

Accepted 25 $5^{\text {th }}$ November, 2021 \& Published 30th November, 2021

In view of the inexpediency and complexity of a reliable determination of this level of the ascertaining experiment at the initial stage (conducting trial experimental, that is, before the start of observation, classes), we considered it necessary to determine the required qualities after a more detailed acquaintance with the educational process and partial testing of pedagogical means of developing the giftedness of students.

Educational-developmental and didacticpsychological approach primarily affects the intellectual resource of the individual. Therefore, in our research, we were guided by various models of educational and extracurricular activities of students, which were applied by us and which were focused on the development of intellectual (cognitive) abilities of students.

This refers to the following models: conceptual "Free class" by Guildford, "Three types of enrichment of the curriculum" by Renzulli and "Taxonomy of learning goals" by Bloom, as well as more specific - free, dialogical, personal, enriching, structural-developing, activating [4].

This division is arbitrary, since all of them are present in one way or another in the process of working with gifted children. Nevertheless, we singled out personal, dialogical and enriching models as the leading ones, since it is they, in our opinion, that provide the necessary cognitive, communicative and reflexive components of the successful development of giftedness. The use of these models in educational and extracurricular activities revealed in more detail the characteristics of the personal qualities and capabilities of clearly and potentially gifted students, on the basis of which the criteria for learning were derived and the measurement of academic abilities was carried out. As a worker, the definition of learning as a complex education was adopted, which depends on many personal qualities and abilities of students, and primarily on intellectual abilities (the ability to analyze, compare, generalize, synthesize, highlight the essential, see learning problems and solve them), and also on the level of cognitive interest and motivation, dedication, flexibility of thinking, self-organization, self-determination, stability in achieving goals, etc.

Learning as an integral individuality of the personality of a gifted student predetermines his different pace of movement in learning, i.e. profound differentiation, especially in terms of the degree of cognitive independence.

Experimental work in work with gifted students: was based on the following principles of pedagogical activity[5]:

- the maximum variety of opportunities provided for personal development;

- the growing role of extracurricular activities;

- individualization and differentiation of training;

- creating conditions for students to work together with minimal teacher participation;

- freedom of choice for students of additional educational services, assistance, mentoring.

When choosing the forms and methods of working with gifted students, we proceeded from the provisions of science and practice, which testifies to the presence of two types of pedagogical interaction - lesson and extracurricular forms.

It should be recognized that it is inappropriate in the conditions of the institution to single out gifted students in special groups for training in all subjects. Gifted students should study in groups with other students. This will create conditions for the further social adaptation of gifted children and, at the same time, for revealing giftedness latent until a certain time, for the maximum possible development of all students to carry out various kinds of project 
CURRENT RESEARCH JOURNAL OF PEDAGOGICS 2(11): 47-53, November

2021 DOI: https://doi.org/10.37547/pedagogics-crjp-02-11-11

ISSN 2767-3278

(C)2021 Master Journals

\section{Crossref doi) 81 Google}

Accepted $25^{\text {th }}$ November, 2021 \& Published $30^{\text {th }}$ November, 2021

activities and creative tasks. Methods and forms of work with gifted students, first of all, should be organically combined with the methods and forms of work with all students and at the same time be distinguished by their originality. To work with gifted students in the classroom, it is recommended to use different versions of the curriculum and training according to individual programs in individual academic subjects.

Can be used, in particular, thematic and problem mini-courses "Brainstorming" in all variants: role-based trainings, the development of research skills and artistic activity in the form of scientific and practical work or creative tests, etc. In addition, for individual work in the lesson, additional material of a developing, teaching, training or controlling nature is used, for example: introduction, training and control of material on various types of speech activity of an increased or high level.

Can be used, in particular, thematic and problem mini-courses "Brainstorming" in all variants: role-based trainings, the development of research skills and artistic activity in the form of scientific and practical work or creative tests, etc. In addition, for individual work in the lesson, additional material of a developing, teaching, training or controlling nature is used, for example: introduction, training and control of material on various types of speech activity of an increased or high level. In this case, it is absolutely logical and effective to use ICT technologies (video, audio books, interactive and audio CDs, DVDs, Internet resources), various types of research work.

As for the forms and methods of extracurricular work, various electives, circles, competitions, attracting students to participate in various olympiads and competitions outside of school and a system of extracurricular research work of students have wide opportunities for identifying and developing the knowledge of gifted students. Here, working in "Small groups", teachers maximize the differentiation of learning, an individual approach, using different methods of work: observation, experiment, research, work with scientific literature, using ICT. This allows us to take into account the different needs and capabilities of gifted children. The most common practices in the university include:

- $\quad$ subject and intellectual Olympiads;

- scientific and practical conferences;

- a system of optional and circle classes;

- summer institutions for gifted students;

- intra-university and inter-university creative contests.

In the course of the experiment, various lesson and extracurricular forms of teaching and development of gifted students were tested, as a result of which the most effective of them were selected (table 1.) .Forms of organizing educational activities with gifted students.

Table 1.

\begin{tabular}{|l|l|}
\hline The form & Tasks \\
\hline Elective & $\begin{array}{l}\text { Taking into account the individual abilities of students } \\
\text { Increasing the degree of independence of students }\end{array}$ \\
\hline
\end{tabular}


CURRENT RESEARCH JOURNAL OF PEDAGOGICS 2(11): 47-53, November

2021 DOI: https://doi.org/10.37547/pedagogics-crjp-02-11-11

ISSN 2767-3278

(C)2021 Master Journals

Crossref dof 81 Google

Accepted 25th November, 2021 \& Published 30th November, 2021

\begin{tabular}{|l|l|}
\hline Elective course & $\begin{array}{l}\text { Expanding the cognitive capabilities of students. } \\
\text { Formation of skills in research, creative and project activities. }\end{array}$ \\
\hline Student conference & $\begin{array}{l}\text { Development of skills and abilities of independent acquisition of } \\
\text { knowledge based on work with popular science, educational and } \\
\text { reference literature. }\end{array}$ \\
\hline Subject week & $\begin{array}{l}\text { Presentation of a wide range of forms of extracurricular } \\
\text { activities. } \\
\text { Increasing the motivation of students to study the educational } \\
\text { field. } \\
\text { Development of creative abilities of students. }\end{array}$ \\
\hline $\begin{array}{l}\text { Scientific Society of } \\
\text { Students }\end{array}$ & $\begin{array}{l}\text { Engaging students in research, creative and project activities. } \\
\text { Formation of analytical and critical thinking of students in the } \\
\text { process of creative search and research. }\end{array}$ \\
\hline Mugs, \\
associations
\end{tabular}

\section{REFERENCES}

1. Djalolov F.F. Causes of Low Assimilation of Knowledge at General Secondary Schools. Middle European jurnal Scientific Bulletin.2021.№11.Issue1.P.580-585.

2. D.A.Sayfullayeva. "Methodology of using innovative technologies intechnical institutions". Psychology and education. Scopus International Journal.(2021) 58(1)

3. Djalolova D.F. The impact of cooperation on the representation of trust in a competitive interaction in a small group. International Journal for Innovative Engineering and Management Research. Vol 10 Issue 06, June 2021 . 92-98. www.ijiemr.org.

4. Djalolov F.F. To the problems of complete assimilation of educational materials at schools. European Journal of Humanities and Educational Advancements №4, Vol.4,December 2020 ISSN:2660-5589. P.55-57

5. Djalolova D.F.,Saidova Kh.Kh., Ergasheva 
CURRENT RESEARCH JOURNAL OF PEDAGOGICS 2(11): 47-53, November

2021 DOI: https://doi.org/10.37547/pedagogics-crjp-02-11-11

ISSN 2767-3278

(C)2021 Master Journals

Crossref do: 81 Google

Accepted 25th November, 2021 \& Published 30 ${ }^{\text {th }}$ November, 2021

M.R. Promotion of practical trainings for the development of the creative abilities of students in special subjects using foreign methods of foreign education method. European Journal of Research and Reflection in Educational Sciences Европа, Vol. 8 No. 11, 2020, p 73-79

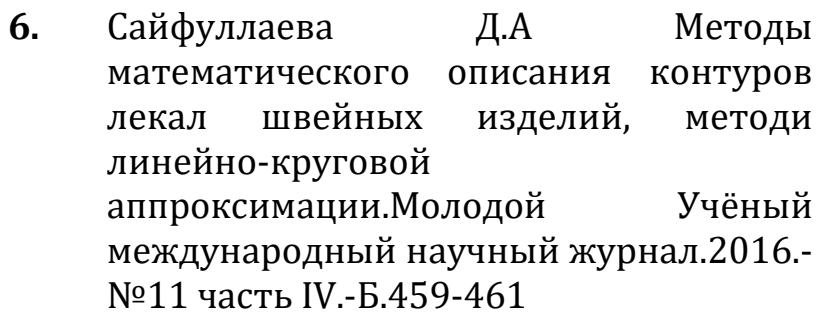

7. Sayfullayeva D.A Innovative and Individual Approach in Professional and Vocational Training of Young People with Disabilities. Eastern European Scientific Journal. Ausgabe 6- 2017 Part I.- P.154-157

8. Dilafruz Ahmadovna Sayfullayeva. "Methodology of using innovative technologies in technical institutions". PSYCHOLOGY AND EDUCATION. Scopus International Journal.(2021) 58(1)

9. Сайфуллаева Д.А Пути повышения эффективности преподавания специальных дисциплин. International conferenceon science and education.Turkey.-2021. B.72-74

10. SayfullayevaD.A, Rustamov E.T, Rayimova D.D, Jabborova M. J., Faridov M. F. CHARACTERISTICS OF TECHNICAL CREATIVITY IN TECHNOLOGICAL EDUCATION. Innovative technologica methodical research journal.2021.B-37-41

11. Sayfullayeva D.A., Juraev A.R., Toshev Yu.N. Innovative project of preparation of students for professional activity // Научно-методический журнал вестник науки и образования № 19 (97). Часть 2. 2020.C.48
12. А.Р.Жўраев, Д.А. Сайфуллаева, Ш.Бахронова Замонавий таълим технологиялар асосида ташкил қилинадиган шахсга йўналтирилган таълим жараёни // Science and Education. № 2020.Б.169-176

13. Olimov Kakhramon Tanzilovich, Sayfullaeva Dilafruz Ahmedovna, Khimmataliev Dustnazar Omonovich, Ashurova Sanobar Yuldashevna, Gaffarov Feruz Hasanovich.Teaching Special Subjects for Students with Disabilities in Preparation for the Profession by Using Innovative Educational Technologies. International Journal of Innovative Technology and Exploring Engineering (IJITEE) ISSN: 2278-3075, Volume-9 Issue1S, November 2019.B.425-429

14. А.Р.Жўраев, Д.А. Сайфуллаева, Ш.Бахронова Замонавий таълим технологиялар асосида ташкил қилинадиган шахсга йўналтирилган таълим жараёни // Science and Education. № 2020.Б.169-176

a) 15. Ахтамов Баходир Рустамович, Муртазоев Азизбек Нусрат угли Проект теплицы подогреваемой альтернативной энергией Наука без границ 2017.- №7(12) .Ст32-35

15. Akhtamov B.R., Murtazoyev A.N. THE TRAINING OF QUALIFIED SPECIALISTS IN HIGHER EDUCATIONAL INSTITUTIONS WITH A TECHNICAL BIAS Путь науки Международный научный журнал, № 6 (52), 2018,Ст17-19

16. Ахтамов Баходир Рустамович, Муродова Зебинисо Каримовна Проведение занятий по предмету Технология и дизайн с учётом индивидуальных особенностей студентов Наука и образование сегодня № 12 (59), 
CURRENT RESEARCH JOURNAL OF PEDAGOGICS 2(11): 47-53, November

2021 DOI: https://doi.org/10.37547/pedagogics-crjp-02-11-11

ISSN 2767-3278

(C)2021 Master Journals

Crossref doi) 81 Google

Accepted 25th November, 2021 \& Published 30th November, 2021

2020,СТ 91-93

17. Dilafruz Ahmadovna Sayfullayeva,

Kakhkhorov Sobir Kh., Bahronova

Sh.I.INCREASING THE.PROFESSIONAL

CREATIVITY OF STUDENTS IN

TEACHING.SPECIALTIES. Проблемы

современной науки и образования

НАУЧНО-МЕТОДИЧЕСКИЙ ЖУРНАЛ.

2020. № 12 (157). Часть 2 С.33

18. Sayfullayeva D.A., Mirdjanova N.N., Saidova Z.Kh. Развитие профессиональных компетенций и творческих способностей студентов высших учебных заведений // Научнометодический журнал вестник науки и образования № 2020.19 (97). Часть 2.C.55

19. Сайфуллаева Д.А, М.Б.Тошпулатова. Предпосылки машинного проектирования и разверток деталей одежды с использованием ЭВМ. Наука, техника и образование Научнометодический журнал. - Москва, 2016. № 2 C. 72-75 